\title{
Editorial de Retratação: retirada de artigo.
}

\author{
Éber Coelho Paraguassu (1) e Karina Figueira (1)
}

\section{EDITORIAL}

\section{Do ocorrido}

No dia 29 de dezembro de 2020 o BJIHS compartilhou em seu volume 2, edição 13, uma cópia com adaptação para o português intitulada "A expansão não planejada e desigual dos cursos de Odontologia no Brasil de 1856 a 2020. "Este compartilhamento foi referente ao trabalho original "Morita, M. C., Uriarte Neto, M., Fontanella, V. R. C., \&amp; Haddad, A. E. (2021). The unplanned and unequal expansion of Dentistry courses in Brazil from 1856 to 2020. Brazilian Oral Research, 35."

No início de janeiro de 2021 recebemos um email dos autores Maria Celeste Morita, Mário Uriarte Neto, Vania Regina Camargo Fontanella e Ana Estela Haddad, que são os autores do artigo original "The unplanned and unequal expansion of Dentistry courses in Brazil from 1856 to 2020." , exigindo a remoção do artigo compartilhado pois os autores não haviam dado autorização para a publicação e aquilo iria gerar questionamentos éticos ao grupo.

Em resposta a esta exigência, o BJIHS por meio de seu Editor Chefe, Dr. Éber Coelho Paraguassu, informou que o artigo "The unplanned and unequal expansion of Dentistry courses in Brazil from 1856 to 2020." estava publicado sob uma licença CCBY e que todos os critérios exigidos para o compartilhamento do artigo foram cumpridos e por isso o compartilhamento não seria removido do BJIHS.

Após alguns meses o BJIHS recebeu um email do escritório de advocacia Piccinini e Serrano, dando ciência ao jornal que os autores não tinham concordado com a decisão do Editor Chefe do BJIHS, Dr. Éber Coelho Paraguassu, pois segundo os autores o arquivo de PDF onde havia sido feito o compartilhamento da cópia com adaptação para o português dava a entender que os autores endossavam aquele compartilhamento e que os autores não queriam ter seus nomes vinculados a publicação alguma no BJIHS.

Após reunião do Editor Chefe do BJIHS, Dr. Éber Coelho Paraguassu, com o setor jurídico do BJIHS, foi decidido que a conduta mais razoável a ser tomada seria aceitar os 
termos dos autores e remover o compartilhamento, fazer uma retratação pública com os autores e expor todo o ocorrido.

\section{Do Editor Chefe e da inicial negativa de retirada do compartilhamento.}

Dr. Éber Coelho Paraguassu informa que inicialmente o compartilhamento não foi removido porque em sua opinião o texto seguia todo o protocolo de compartilhamento de publicações CCBY. O editor ressalta que em duas oportunidades a publicação deixava explicito que aquele artigo era apenas uma cópia com adaptação para o português e que os autores não endossavam seu compartilhamento, como pode ser visto na imagem 1.

\section{Imagem 1}

\section{DECLARAÇÂO CC BY*}

Este artigo é uma reutilização em forma de cópia com adaptação para o português do Artigo Original " Morita, Maria Celeste, et al. "The unplanned and unequal expansion of Dentistry courses in Brazil from 1856 to 2020." Brazilian Oral Research 35 (2020)." 33 Esta Cópia com adaptação para o Português segue os preceitos Creative Commons CC BY 4.0 (https://creativecommons.org/licenses/by-nc/4.0/deed.en) disponibilizado pelo periódico responsável pela publicação original ( https://www.scielo.br/scielo.php?script=sci arttext\&pid=S1806-

83242021000100208\&lng=en\&nrm=iso\&tlng=en). Esta cópia com adaptação para o português não foi submetida pelos autores e tão pouco tem qualquer tipo de endosso dos autores ou do jornal responsável pela publicação original, a não ser a autorização legal de livre compartilhamento e adaptação CC BY 4.0.

Imagem referente a parte do texto compartilhado no BJIHS.

Ocorre que a ficha catalográfica do artigo, como pode ser vista na imagem 2, poderia dar a entender que os autores foram os responsáveis pelo envio do compartilhamento, fato este que não corresponde com a verdade dos fatos, pois a cópia com adaptação foi realizada pela Editora Karina Figueira.

\section{Imagem 2}

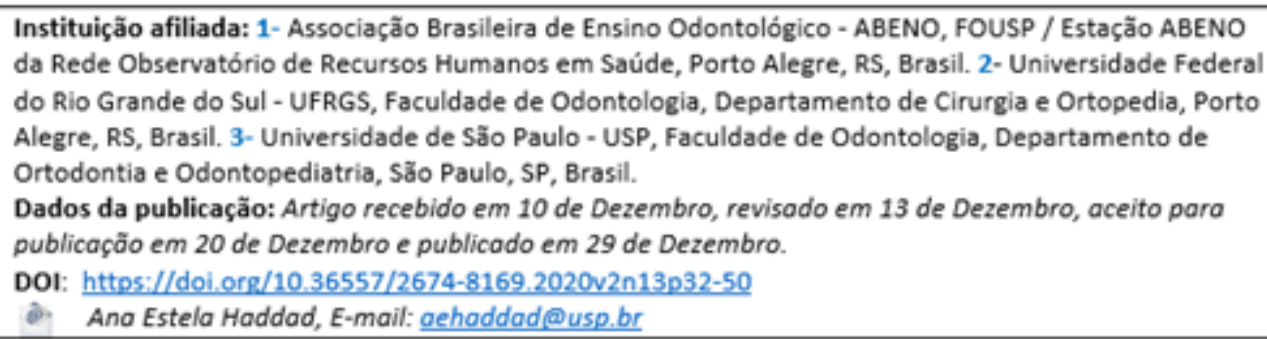


Imagem referente a ficha catalográfica compartilhada no BJIHS.

Inicialmente o Editor Chefe achou que este fato era pouco relevante e embora pudesse dar a entender que os autores enviaram o artigo e, portanto, endossavam sua publicação, essa impressão seria desfeita com o explicitado na imagem 1.

Após conversa com o setor jurídico, o Editor Chefe entendeu que os autores estavam corretos em suas reivindicações e o leitor mais desatento poderia sim ter a impressão de que os autores Maria Celeste Morita, Mário Uriarte Neto, Vania Regina Camargo Fontanella e Ana Estela Haddad, eram também os autores da cópia com adaptação para o português "A expansão não planejada e desigual dos cursos de Odontologia no Brasil de 1856 a 2020. " e que apenas as informações contidas na imagem 1 não seriam suficientes para solucionar alguma dúvida que o leitor mais desatento pudesse vir a ter.

\section{Da Retratação}

Após todo o exposto, o BJIHS vem a público informar que os autores Maria Celeste Morita, Mário Uriarte Neto, Vania Regina Camargo Fontanella e Ana Estela Haddad, não possuem relação alguma com o compartilhamento da cópia com adaptação para o português "A expansão não planejada e desigual dos cursos de Odontologia no Brasil de 1856 a 2020. "

O compartilhamento já foi removido do jornal e das bases indexadoras.

Em nome de todo o corpo editorial o BJIHS pede formalmente desculpa aos autores por todo este imbróglio envolvendo seus nomes e que nunca foi intenção deste jornal causar qualquer dano ou prejudicar a imagem de nenhum dos autores ou quem quer que seja.

O BJIHS repudia as práticas acadêmicas ilícitas e apoia firmemente o compartilhamento CCBY pois entendemos que o conhecimento não pode ficar restrito a um veículo, idioma ou local. Entendemos também que a grande maioria das produções científicas no Brasil são financiadas pelo dinheiro do pagador de impostos e, portanto, todo o conhecimento advindo deste financiamento pertence a todos, tendo por obrigação o compartilhamento massivo no maior e mais diversos número de veículos científicos, para que o conhecimento seja difundido de maneira mais democrática e de fácil acesso. É um erro falar em propriedade intelectual quando o financiamento é do contribuinte, entretanto entendemos também que isto é apenas uma opinião do corpo editorial deste jornal e existe uma lei vigente sobre propriedade intelectual que deve ser respeitada em seu pleno.

Oferecemos também aos autores um espaço para que caso queiram acrescer alguma informação ou corrigir algo dito nesta retração, que o façam através de carta em resposta a este editorial. A carta será publicada integralmente na edição do mês em que a recebermos. 
Instituição afiliada: 1- Specialized dentistry Group.

Dados da publicação: Artigo recebido em 10 de Março, revisado em 15 de Maio, aceito para

publicação em 20 de Maio e publicado em 27 de Maio.

DOI: https://doi.org/10.36557/2674-8169.2021v3n5p04-08

Karina Figueira figueira@periodicosbrasil.com.br

This work is licensed under a Creative Commons Attribution 4.0 International

License. (c) (7) 